\title{
Separation/Divorce Sexual Assault
}

\section{The Contribution of Male Support}

\author{
Walter S. DeKeseredy \\ University of Ontario Institute of Technology, Oshawa, Canada \\ Martin D. Schwartz \\ Danielle Fagen \\ Ohio University, Athens \\ Mandy Hall \\ University of Hawaii-Manoa
}

\begin{abstract}
Although several studies find that the most dangerous part of an intimate relationship for women is when it breaks up, relatively few studies look at women who want to break up a relationship, are in the process of leaving, or who have left a relationship. This qualitative exploratory study looks at incidents of sexual assault committed by former husbands or cohabitants in the lives of rural women in Ohio. Male peer support, which has previously been examined only in studies of college men and men in urban areas, was a constant theme among this study's respondents, in addition to patriarchal control and the use of alcohol and drugs. These women suffered multiple serious sexual assaults and experienced other harms, including psychological assaults and the destruction of prized objects.
\end{abstract}

Keywords: sexual assault; separation/divorce; violence; male peer support

Cince the 1970s, social scientists have greatly enhanced an empirical and theoretical understanding of various types of woman abuse in ongoing heterosexual relationships. However, although we know that breaking up with a violent man is one of

\footnotetext{
Authors' Note: This article was presented at the 2004 annual meeting of the American Society of Criminology, Nashville, Tennessee. The research reported here was supported by National Institute of Justice Grant 2002WG-BX-0004 and financial assistance provided by the College of Arts and Sciences and the Office of the Vice President for Research at Ohio University. Arguments and findings included in this article are those of the authors and do not represent the official position of the U.S. Department of Justice or Ohio University. The authors would like to thank Shahid Alvi, Bernard Auchter, Karen Bachar, the California Coalition Against Sexual Assault, Megan Cameron, Katharine Darke, Joseph Donnermeyer, Judith Grant, Carolyn Joseph, Mary Koss, My Sister's Place, the Ohio Domestic Violence Network, Claire Renzetti, McKenzie Rogness, Leora Rosen, and all the service providers who worked with us for their input. Please send all correspondence to Walter S. DeKeseredy, e-mail: walter.dekeseredy@uoit.ca. All of the names of women who participated in the study and who are quoted here have been changed to maintain confidentiality.
} 
the most dangerous events in a woman's life (J. Campbell et al., 2003), relatively little attention has been paid to the victimization of women who want to leave, are in the process of leaving, or who have left their marital/cohabiting partners. Furthermore, the limited work that has been done on this topic has focused on physical violence. ${ }^{1}$ For example, Fleury, Sullivan, and Bybee (2000) found that $36 \%(n=49)$ of the women $(N=135)$ who participated in their longitudinal study were physically attacked by a male ex-partner during a 2-year period. Moreover, $40 \%$ of the 75 divorced men who participated in Arendell's (1995) study stated that they threatened or used violence against their former spouses after separation. Abuse, of course, is multidimensional in nature and a few studies show that women are also at high risk of being sexually assaulted during and after separation/divorce (Bergen, 1996; DeKeseredy \& Joseph, 2006; Finkelhor \& Yllo, 1985; Kurz, 1995; Russell, 1990). Still, almost all of the research on this problem, regardless of whether it is qualitative or quantitative, was done in urban areas, such as Boston and San Francisco.

Thus, a key objective of this article is to help fill a research gap by presenting results of an exploratory qualitative study of separation/divorce sexual assault in some rural areas of Ohio. Note too that one of the key risk factors identified in this study is patriarchal male peer support, which is defined here as "attachments to male peers and the resources they provide which encourage and legitimate woman abuse" (DeKeseredy, 1990, p. 130). Except for Websdale's (1998) Kentucky study, no prior empirical attempt has been made to discern the existence, nature, and content of proabuse male social networks in rural U.S. communities. In fact, most male peer support research is quantitative in nature and limited to explaining violence on college campuses (Schwartz \& DeKeseredy, 1997). Moreover, no study concentrates on whether male peer support contributes to sexual assault during or after the termination of any type of intimate relationship. Thus, the research described here also attempts to enhance a sociological understanding of the ways in which sexist male peer group dynamics perpetuate and legitimate the sexual abuse of separated/divorced rural women.

\section{Conceptualization of Separation/Divorce}

Can only couples that live apart be considered separated/divorced? Many surveys of marital rape such as Finkelhor and Yllo's (1985) and the U.S. National Violence Against Women Survey (Tjaden \& Thoennes, 2000), as well as surveys of nonsexual types of woman abuse, seem to define separation/divorce this way. This approach is problematic because it neglects assaults after women's decisions and/or attempts to leave while they are locked in relationships (Mahoney, 1991; Ptacek, 1999). Many men have a "fanatical determination" to not let their spouses/live-in partners go and will use violence "to keep them in their place" (Russell, 1990).

Another point to consider is that many women defy men's patriarchal control by emotionally separating from them (DeKeseredy, Rogness, \& Schwartz, 2004). Emotional separation, a major predictor of a permanent end to a relationship, is 
defined as a women's denial or restriction of sexual relations and other intimate exchanges (Ellis \& DeKeseredy, 1997). Emotionally exiting a relationship can be just as dangerous as physically or legally exiting one because it too increases the likelihood of male violence and sexual abuse (Ellis \& DeKeseredy, 1997; Kayser, 1993; Kirkwood, 1993; Markman \& Notarious, 1994; Russell, 1990).

In sum, separation/divorce is not simply a function of proximity. Moreover, a woman does not have to be legally tied to a man to experience the pain and suffering caused by sexual or physical assault (Bergen, 1996). For example, Brownridge and Halli's (2001) review of 14 studies - 8 done in the United States, 5 in Canada, and 1 in New Zealand-reveals "quite dramatic" differences in violence rates obtained from married persons and cohabiters. In fact, they found that typically, the rate of violence for the latter exceeds that of the former by 2 times, but the difference can be greater than 4 times. Cohabiting women are also more likely to experience more severe types of violence than their married counterparts. Furthermore, Canadian national representative sample survey data show that many women are sexually abused by their common-law partners, and male cohabitants are more likely to sexually abuse their partners than those in casual or serious dating relationships (DeKeseredy \& Schwartz, 1998a). As J. Campbell (1989) pointed out, "A marriage license probably does not change the dynamics of sexual abuse within an ongoing intimate relationship" (p. 336).

Research also shows that male cohabitants are at higher risk of being sexually abusive than married men. For example, Finkelhor and Yllo (1985) found that $23 \%$ of the cohabiting women in their sample experienced forced sex, whereas $3 \%$ of married women were harmed this way. Note too that $25 \%$ of the women who reported forced sex were legally separated/divorced. Thus, based on the above arguments and data presented elsewhere (e.g., DeKeseredy et al., 2004), here, we use the term separation/divorce to mean physically, legally, or emotionally exiting a marital/cohabiting relationship. Furthermore, our project focuses on womeninitiated separations/divorces because as Sev'er (1997) reminded us, "They are the decisions that challenge male hegemony the most" (p. 567). We also use a broad definition of sexual assault because it, like the physical and psychological abuse of women, takes many shapes and forms.

\section{Broad Definition of Sexual Assault}

There are a number of problems with narrow definitions of sexual assault, which have been covered elsewhere (DeKeseredy, 2000). Unlike many, if not most, studies of sexual assault, a broad definition is used here that is not restricted to acts of forced penetration. Many women experience a wide range of sexually abusive behaviors, such as assaults when they were drunk or high or when they were unable to give consent (Bachar \& Koss, 2001; Schwartz \& Leggett, 1999). Married and cohabiting women also experience other kinds of threats that can result in painful unwanted sex and 
"blackmail rapes." Consider what "Mrs. Brown" described to Russell (1990). Just because there was no threat or actual use of force does not mean that her experience was not frightening or highly injurious, and she clearly labels what her first husband did as rape:

The worst raping occasion was in the morning I awoke in labor with my first child. The hospital I was booked into was a thirty-minute drive away, and this being the first time I had undergone childbirth. I had no idea of how close I was to giving birth, or what was to happen to me next. I labored at home for a few hours until perhaps 11:00 a.m., and then said to my ex-husband that I thought we'd better go to the hospital. The pains were acute and I was panicking that I would not be able to bear them. He looked at me, and said, "Oh, all right. But we'd better have a screw first, because it'll be a week before you're home again." I couldn't believe it, even of him. "Please, W., take me to the hospital," I begged as another contraction stormed across my body. "Not until we have a screw," he insisted. I wept, I cried, I pleaded, but he wouldn't budge. The pleading went on until midday, by which time I was frantic to get nursing help. He stood adamant with his arms crossed, a smirk on his face, and jiggling the car keys as a bribe. In the end I submitted. It took two minutes, then we dressed and drove to the hospital. The baby was born five hours later. (Russell, 1990, p. 338)

Most definitions also do not include unwanted sex "out of a sense of obligation" (Bergen, 1996), sexual relations stemming from ex-partners' threats of fighting for sole custody of children and other acts that do not involve the use of threats of force. Unfortunately, excluding the abusive behaviors identified here exacerbates the problem of underreporting and ultimately underestimates the extent of sexual assault (DeKeseredy et al., 2004). Thus, guided by Koss, Gidycz, and Wisniewski's (1987, p. 166) conceptual and empirical work, below is how we classified the types of sexual assault described by our interviewees:

Sexual contact includes sex play (fondling, kissing, or petting) arising from menacing verbal pressure, misuse of authority, threats of harm, or actual physical force.

Sexual coercion includes unwanted sexual intercourse arising from the use of menacing verbal pressure or the misuse of authority.

Attempted rape includes attempted unwanted sexual intercourse arising from the use of or threats of force or the use of drugs or alcohol.

Rape includes unwanted sexual intercourse arising from the use of or threats of force and other unwanted sex acts (anal or oral intercourse or penetration by objects other than the penis) arising from the use of or threat of force or the use of drugs or alcohol.

\section{Male Peer Support for Sexual Assault}

We use male peer support to refer to the multidimensional attachments men form to male peers who themselves sexually assault women and/or provide resources that perpetuate and legitimate such assaults. There are a variety of sociological and social 
psychological processes by which peers influence men to sexually victimize women (Schwartz \& DeKeseredy 1997), but the key point here is that such all-male groups encourage, justify, and support the abuse of women by their members. For example, such men provide informational support, which refers to the guidance and advice that influences men to sexually abuse their partners. Male peer support theory sees such support as a motivational factor, allowing men to develop proabuse attitudes and behaviors as a result of the encouragement and support of other males, if not of the broader culture at large (Schwartz, DeKeseredy, Tait, \& Alvi, 2001).

This form of peer pressure that legitimizes the sexual objectification of women and the sexual exploitation of them can be found in all types of cultures throughout the world. For example, Wilson (1996) found that inner-city African American men found themselves under considerable peer pressure

to be sexually active. They said that the members of their peer networks brag about their encounters and that they feel obligated to reveal their own sexual exploits. Little consideration is given to the implications or consequences of sexual matters for the longer-term relationship. (p. 99)

Far from Wilson's research site, H. Campbell (2000) found that male pub drinking practices in rural New Zealand reinforced dominant understandings of legitimate masculine behavior. In this rural area, male pub behavior included men from across the community, making pubs "the key sites for maintaining the legitimacy of hegemonic masculinity in the wider community" (H. Campbell, 2000, p. 579).

As noted above, most of the work on male peer support theory is quantitative in nature and conducted on college campuses (DeKeseredy \& Schwartz, 1998b). A few researchers have both used qualitative methods and left the college campus to study the relationship between male peer support and various types of woman abuse in urban areas of concentrated disadvantage (Anderson, 1999; Bourgois, 1995; Wilson, 1996). Sinclair (2002) found in a qualitative study that male peer support helped to explain woman abuse behavior among socially displaced youth in an eastern Ontario city. Furthermore, DeKeseredy and Schwartz (2002) offered a male peer support theory of woman abuse in public housing but did not gather any data specifically on this topic. The topic of interest in this article-sexual assault of women who are breaking up or trying to break up intimate relationships-is one outside the purview of all of the prior studies, as is for the most part the study of male peer support for sexually aggressive men in rural areas.

\section{Method}

Immediately after receiving approval to conduct this study from Ohio University's institutional review board, the research team began this project by developing a "preparatory component of qualitative investigation" (MacLean, 1996). This involved 
several meetings, electronic mail exchanges, and in-depth telephone conversations with leading researchers in the field, ${ }^{2}$ local shelter staff, sexual assault survivor advocates, police officers, mental health workers, and others with a vested interest in curbing the pain and suffering uncovered by this research. Service providers were given copies of the research proposal and screening questions, and they were helpful in shaping the final versions of each. They sensitized the research team to such issues as the influence of broader Ohio state politics and put us into contact with service providers and criminal justice officials throughout Ohio, such as those affiliated with the Ohio Domestic Violence Network and the Ohio Coalition Against Sexual Assault. Practitioners also referred 6 of the 43 women who participated in this study. As Schechter (1988) pointed out, activists and practitioners are experts on woman abuse and "can help researchers formulate sophisticated and intellectually rich questions" (p. 311). ${ }^{3}$

Prior data on the relationship between separation/divorce and nonlethal forms of woman abuse (e.g., beatings) have been primarily derived from surveys. To develop a richer understanding of these issues, it is necessary to listen to women's voices because it "may be the only way to describe a complex reality for which we have few names" (Mahoney, 1991, p. 41).

The effects of the geography, economy, and culture of rural communities like those in Ohio and how they affect the residents has been discussed. However, these same problems present themselves in any attempt to gain access in a telephone or self-report survey (Weisheit, Falcone, \& Wells, 1996). Like women living in other poor rural communities, a sizeable portion of those residing in the counties where this study was conducted cannot afford telephones or cars (Krishnan, Hilbert, \& VanLeeuwen, 2001; Lewis, 2003). To make matters worse, many rural women have abusive current or former partners who "feed off of" women's isolation and poverty to magnify their isolation. And they often use tactics such as disabling cars or forbidding women to leave the house (Websdale, 1998).

Techniques like those employed by Bowker (1983) in Milwaukee generated our sample. For example, the advertisement presented in Figure 1 was placed once a week during two different 6-week periods in a free newspaper available throughout Athens County, Ohio. Also, posters about the study were pinned up in public places, such as courthouses, and were given to social service providers who came into contact with abused women. In addition,

Two local newspapers gave considerable coverage to the project;

Ohio University sent out a press release to newspapers and other Ohio-based media;

Three local radio stations and Ohio University's television station carried public service announcements about the study;

The principal investigator and the director of the local shelter appeared on a local television news show to discuss this project and broader issues related to it;

The Ohio Domestic Violence Network and other agencies told interested parties (e.g., rural shelter workers) about the study and helped to recruit participants; 


\section{Figure 1}

Newspaper Advertisement

Call for interested women of Athens, Hocking, and Vinton Counties

for participation in an Ohio University research project

Have you ever had unwanted sexual experiences while trying to leave your husband or male live-in partner?

Or, have you ever had unwanted sexual experiences after you left your husband or male live-in partner?

We would greatly appreciate your participation in a confidential interview. Your name will not be given to anyone.

We will pay you $\$ 25.00$ for your time and transportation costs. Also, we will talk to you at a time and location of your choosing.

If you would like to be interviewed, please call Mae at (xxx)-xxxxxxx or Carolyn at (xxx) xxx-xxxx.

Local shelter staff, a police department social worker, employees of the county sheriff's department, Planned Parenthood, Women's Center staff at a local 2-year college, and employees of the local Sexual Assault Survivor Advocate Program informed possible respondents about the study;

Ohio University sociologist Judith Grant told women who participated in her addiction study about our research; and

Index-like cards with the information provided in the recruiting poster were routinely placed on top of newspaper boxes inside stores and on sidewalks in Athens.

From early March 2003 until early April 2004, two female research assistants carried cellular phones 24 hours a day to receive calls from women interested in participating in the study. Callers were told the purpose of the study and were then asked a series of screening questions to determine their eligibility to be interviewed. The main criteria were being 18 years of age or older and having ever had any type of unwanted sexual experience when they wanted to end, were trying to end, or after 
they had ended a relationship with a husband or live-in male partner. If they met the selection criteria, the women were then invited to a semistructured face-to-face interview at a time and place of their choosing, and they were paid US $\$ 25.00$ for their time. They were also given US\$7.75 for travel expenses and an index card listing the locations and phone numbers of local support services for survivors. Index or palm cards are much safer than sheets because they minimize the likelihood of abusive ex-partners and others (e.g., ex-partners' male friends) discovering that respondents shared their abusive experiences with others. Of course, interviewees were also invited to contact the research team at a later time if they had questions and concerns. In sum, although the research team was deeply committed to generating rich qualitative data, it was equally, if not more, concerned with ensuring respondents' safety in communities where most residents know each other.

Six interviews were conducted via the phone, five were held off campus, and the rest were done in an Ohio University office. The semistructured interview schedule is presented in the appendix, and it should be noted in passing that most of the participants who came to the campus to be interviewed did not disclose how they got there. However, we assume that friends or relatives drove them. Furthermore, all of the participants did not disclose how they had access to telephones. It is reasonable to assume that they felt that revealing such information would jeopardize their safety.

Female research assistants tape-recorded and transcribed all of the interviews. Most of the interviews took about 90 minutes, and a total of 43 women participated in this study. Posters placed in public places attracted most of our respondents $(n=27)$. Of the respondents, 8 women called after exposure to advertisements or media stories about the study, and the same number were referred to us by individuals or organizations. Most of the respondents $(n=30)$ lived in Athens County, 3 lived in Hocking County, 1 lived in Vinton County, and 9 lived in other rural parts of the state. The mean age of the sample was 35 , and the mean income for 2002 was US $\$ 13,588$. Of the respondents, $65 \%(n=28)$ had some type of postsecondary education and close to half of the participants were unemployed. Of the 25 who had been married, all got divorced or legally separated, but only 5 remarried. Most of our respondents also had children.

\section{Findings}

Earlier we listed the definitions of the four types of sexual assault used in this study. The number of respondents who ever experienced one or more of these behaviors is presented in Table 1. Only a few of the 43 respondents experienced just one of the above forms of separation/divorce sexual assault, and virtually all experienced rape or attempted rape. As stated previously, blackmail rapes are not uncommon. For example, Tina wanted to leave her partner but was afraid of losing her children. Asked why her partner sexually assaulted, she replied, 
Table 1

Separation/Divorce Sexual Assault Prevalence Rates $(N=43)$

\begin{tabular}{lrc}
\hline Type of Sexual Assault & $n$ & Percentage \\
\hline Sexual contact & 19 & 44 \\
Sexual coercion & 32 & 74 \\
Attempted rape & 8 & 18 \\
Rape & 35 & 81 \\
\hline
\end{tabular}

Table 2

Nonsexual Abuse Prevalence Rates $(N=43)$

\begin{tabular}{lcc}
\hline Type of Nonsexual Abuse & $n$ & Percentage \\
\hline Physical violence & 36 & 84 \\
Psychological abuse & 38 & 88 \\
Economic abuse & 30 & 70 \\
Abuse of pets & 5 & 12 \\
Stalking & 16 & 37 \\
Destruction of prized possessions & 22 & 51 \\
\hline
\end{tabular}

Um, to punish me for leaving him. To punish me for getting pregnant, um, to punish me for embarrassing him and um, to control me. . . . And then something would happen and he would know it was getting close to the end of our relationship once again and he would start it. And the whole time I would be crying, but I couldn't cry loud enough because if his parents heard us he swore he would take our children away. I know he did this when he thought I was getting ready to leave and he knew that I couldn't live without my children.

Women who are the victims of intimate interpersonal violence are rarely victimized only by sexual assault. Rather, they typically suffer from a variety of male behaviors that include physical violence, psychological abuse, economic blackmail or abuse such as denying the woman money even if she earns a wage, harm to animals or possessions to which she has an attachment, or stalking behavior. Most (80\%) of the women here were victimized by two or more of these forms of abuse. The rates at which they reported this abuse are listed in Table 2, where each different type of abuse is counted once, but a single person can be counted in more than one category.

Joan was one interviewee who was harmed by various types of abuse during the process of exiting her relationship:

Well, what happened was that he got drunk and wanted sex from me and I told him no. I said, "Stay away from me. I can't stand you when you're drinking. Get away from 
me." He started grabbing my butt, and playing with my legs, and trying to grab my boobs. And everything, anything to get what he wanted. And I told him, I kicked him in the leg and I told him, "Get away from me." And then got into a fight over it and then he started throwing stuff at my face and I went to the phone and I said, "I'm gonna call your probation officer." I says, "If you don't leave me alone and you've been drinking, you're acting like an ass. Leave me the hell alone." And he wouldn't. He unplugged the phone. I plugged it in, I plugged it, you know. It was back and forth. He unplugged, I plugged it in. He unplugged it, I plugged it in. . . . When he was trying to prevent me from getting the phone, he stepped on my foot, which fractured the top of my foot. I was on crutches for two weeks.

Table 2 shows that most victims of separation/divorce sexual assault are also hurt by other highly injurious acts. Sometimes they are not the only ones injured by ex-partners. For example, 19\% of our respondents stated that their partners abused their children and one woman believes that her ex-partner raped her as a means of killing her unborn child. Below is what Trina's ex-husband did to her daughter:

He came back October of the same year for a so-called emergency visitation, and he was able to take my daughter away from me for eight hours even though the DNA had never been proven. And, when my daughter finally came back, she had severe diaper rash, smelled like cigarettes and alcohol, and had bruises right, right on her thighs and on her wrists.

Some men did not hit their children or force them to have sex but behaved in other ways that are sexually and psychologically abusive. Below is one example that involved the use of pornography shortly after this man realized that his wife was going to leave him:

I walked into him masturbating in front of my children to Penthouse. . . . There were naked pictures, well not naked, but pictures of me in a bra and underwear that he had stolen and had developed.

When is the most likely time for separation/divorce sexual assault to occur? As other studies discover (e.g., Sev'er, 1997), it may be when a woman expresses a desire to leave a relationship. Of our respondents, 74\% $(n=32)$ stated that they were sexually assaulted at that time, $49 \%(n=21)$ were sexually abused while they were trying to leave or while they were leaving, and $33 \%(n=14)$ were victimized after they left. Obviously, many of these women were victimized at two or more of these times.

Although it is difficult to make hard comparisons from small numbers, there is no question that in this sample, the formerly married women reported a higher rate of sexual assault at each stage than did cohabiting women. For example, compared to cohabiting women $(33 \%, n=6)$, married women $(47 \%, n=12)$ were more likely to report being abused while still in the relationship, before expressing a desire to exit, 
trying to exit, or exiting their relationships. At the next stage, when the women reported that they wanted to leave their abusive relationship, 20 of the 25 married women $(80 \%)$ stated that they were sexually assaulted, whereas 12 of the 18 cohabiting women $(67 \%)$ stated that their assaults occurred at this point in time. These marital status variations data are obviously distinct from those uncovered by Finkelhor and Yllo (1985) and may be the result of married men perceiving greater threats to their sense of entitlement and a stronger adherence to the belief that their wives are their property (Bergen, 1996).

As stated earlier, male peer support was a constant theme among our respondents, which is not surprising given that this determinant is strongly associated with other types of woman abuse, such as date rape and wife beating (Bowker, 1983; DeKeseredy \& Schwartz, 1998a). For example, 67\% $(n=29)$ of the women we interviewed reported on a variety of ways in which their partners' male peers perpetuated and legitimated separation/divorce sexual assault. Three methods in particular stand out: frequently drinking with male friends, informational support, and attachment to abusive peers. Informational support refers to the guidance and advice that influences men to sexually, physically, and psychologically abuse their female partners; attachment to abusive peers is defined as having male friends who also abuse women. These factors are identical to those found to be highly significant in predicting which men on college campuses will admit to being sexual predators (DeKeseredy \& Schwartz, 1998b; Schwartz et al., 2001).

The first factor is frequent drinking with friends. Such drinking has often been associated with the development of a particular kind of masculinity that objectifies women and endorses male behavior that can be physically and sexually violent (H. Campbell, 2000; DeKeseredy \& Schwartz, 2005). Although 77\% $(n=33)$ of the women said that their former partners frequently drank alcohol, 63\% $(n=27)$ said their partners spent large amounts of time with their male friends, and most of the time spent together involved drinking alcohol. Furthermore, as is the case with college men who sexually abuse women, "nights out drinking with the boys" were seen by many respondents as contexts that often supported patriarchal conversations about women and how to control them. ${ }^{4}$ As Susan told us,

Um, they're basically like him. They sit around, talk about women and gossip. They're the biggest gossips there ever was. But they sit around and brag how many times they get it and how they keep their women in line and you know just like crap, you know.

The social settings described by Susan and other respondents are also examples of the second factor of informational support, although these were not restricted to group drinking events. For example, one respondent's abusive partner spent much time with his cousin, a man who "hated women" and who often called them "fuckin bitches" and "whore sluts." Note, too, that although most of the participants did not explicitly label their partners' peers as patriarchal, most of them are. As Lynn said, 
"And they just think women are their property and they can lay 'em anytime they want to. That's just their whole attitude about it." Furthermore, $47 \%(n=20)$ of the sample stated that they knew their partners' friends also physically or sexually abused women, which indicates that attachment to abusive peers also contributes to separation/divorce assault. In fact, Betty told us that all of her ex-partners' friends hit women or sexually assault them, and several women told us that they directly observed their partners' friends abusing female intimates. Jackie is one such participant: "I watched a friend of his who shoved a friend of mine up against a wall . . . and try to, you know, have his way with her."

A few perpetrators also enlisted the help of their friends to sexually abuse some of the women we interviewed. Such male peer support frequently involved forcing women to have sex with friends. Consider what happened to Marie:

\begin{abstract}
Well, him and his friend got me so wasted. They took turns with me and I remembered most of it, but, um, there was also drugs involved. Not as much on my behalf as theirs. I was just drunk. And I did remember most of it and the next morning I woke up feeling so dirty and so degraded and then it ended up getting around that I was the slut. . . . And in my eyes that was rape due to the fact that I was so drunk. And I definitely didn't deserve that. And I was hurting. I was hurting the next day.
\end{abstract}

This incident is similar to what Sanday (1990) uncovered in her study of fraternity gang rape. In groups, some men do not rely on force to have sex with women but rather, use alcohol or drugs to "work a yes" out of them. In other words, some perpetrators, either alone or in a group, purposely get women so drunk that they cannot resist their advances, which is a form of felony forcible rape in Ohio and most other states. Although the incident described below by Carrie did not involve male peer support, it is another glaring example of using alcohol as a means of working a yes out:

I agreed to meet with him to discuss visitation and child support for our daughter and I wanted to go to a public place after everything he had done because it wasn't just sexual, it was mental, physical. And I showed up there. I had a couple of friends who were sitting throughout keeping an eye on me. Ordered the drink, got up to use the bathroom, drank my drink and that was pretty much the last thing I remembered until the next morning when I woke up with a killer headache and my daughter crying in her crib. . . . He was in bed next to me. . . . I had strangulation marks around my neck. I had marks around my wrists and an open wound on my face and he had obviously had sex.

A few women who were forced to have group sex were also beaten after going through brutal degradation ceremonies. This is what happened to Janet:

He ended up bringing someone into the relationship, which I didn't want, but he told me that if I didn't do it he would leave me. And I ended up staying with him. He was more into group sex and, and uh trying to be the big man. He wanted sex in a group 
thing or with his buddies or made me have sex with a friend of his. See one time he made me have sex with a friend of his for him to watch, and then he got mad and hit me afterwards. I mean he tied me up so I could watch him have sex with a 13-year-old girl. And then he ended up going to prison for it. So, I mean it was nasty.

Lorraine recalled this incident that occurred during the end of her relationship:

He wanted me to have sex with a few people. Okay, like I was telling you earlier, and I didn't want to. . . . And, uh, I finally did. And then I got beat for it because I did. I tried not to, but then when we did, I got beat.

Of the sample, $79 \%$ told us that their partners strongly believed that men should be in charge and in control of domestic household settings. For example, Marie said that her ex-husband "wanted to be in control. He was in control for us, or you know I felt it." Moreover, like Joan's ex-husband, many of the interviewees' partners isolated them to maintain control:

He didn't allow me to socialize at all. My place was at home with the children and that's where I was most of the time. The only thing I went out for was if they had a parent-teacher conference at school. I went for that. But no, I had no outside contact.

This is how another respondent's partner treated her until she managed to leave him:

His favorite thing was, "If you are not going to be at work, you're going to be here cooking and cleaning, doing laundry. And if I ever catch you sitting on your ass, I am going to beat the fuck out of you, you know."

Most respondents stated that they were raped during or after separation/divorce because their partners wanted to show them "who was in charge." Tanya was one of many interviewees who had a partner that was determined not to let her go:

He did it because I was his and he felt he could. And it was his way of letting me know that, ah, first of all, of letting me know that I was his. And secondly, letting me know that um, that I wasn't safe anywhere. And I, when we were together, when he had forced me to go back together with him, ah, he, ah . . . raped me as another form of, of possession. And I think also as a reminder of what could happen. And ultimately, at one point, I believed that he raped me as part of his means of killing my unborn child.

Nickie had similar experiences:

I was his property that he wanted to own me. And I was his. That's how he looked at it. I was his property and that's all that I felt I was to him, was just a lay, you know. But that's 
all he wanted me for was to satisfy himself. . . . He would deprive me. It was more of a mental torture, emotionally, mental torture than physical except in the sex it was physical. "You're mine and I'm gonna have you whether you want it or not. I want you." He was in control. And that's what it's all about with men like that. They have to be in control.

The fact that close to $80 \%$ of the men who abused their partners adhered to the ideology of familial and/or societal patriarchy may also partially explain why so many perpetrators had peers who were sexist or abusive. For example, DeKeseredy and Schwartz (1998a) uncovered a strong statistical relationship between Canadian college men's patriarchal attitudes and beliefs and their affiliations with male peers who perpetuate and legitimate physical, sexual, and psychological abuse in dating relationships. More specific, these researchers found that Canadian college men who report abusing their girlfriends and dating partners are more likely than those who do not report abusive behavior to endorse an ideology of familial patriarchy. They also found that these men are even more likely to be abusive if male peers support their sexist ideology and injurious behaviors.

Below is one major example of how male peers supported an interviewee's husband's "right" to maintain his patriarchal control with abuse. This incident happened shortly after her husband found out that she wanted to leave him:

I remember my husband making me have sex with him one time when people were in the next room and none of them guys would come in and help me. And they knew he was hitting me, but they figured that he was my husband. If it were a stranger it would have been different.

Did male peers teach interviewees' partners to engage in separation/divorce sexual assault, or did abusive men simply seek the friendship and support of violent peers? These are important empirical questions that can be answered only empirically. It is hoped that future research on separation/divorce sexual assault will be specifically designed to uncover richer data on the complex relationship between patriarchy, male peer support, and the abuse uncovered by this study.

A few studies find that the contribution of pornography to woman abuse in dating is related to male peer support (DeKeseredy \& Schwartz, 1998a; Schwartz \& DeKeseredy, 1998). For example, some men learn to sexually objectify women through their exposure to pornographic media (Jensen, 1995), and they often learn these lessons in groups, such as pornographic film showings at fraternity houses (Sanday, 1990). In a similar manner, some rural Ohio survivors of separation/divorce sexual assault said that their partners consumed pornography with their male friends while drinking excessive amounts of alcohol. Agnes is one interviewee who experienced this problem:

They were drinking and carrying on and they had, um, they had a bunch of porno stuff in the garage and I had walked in and I had started to tear it up. And I was, I was, I thought it was gross. I was mad at it. I was mad at him for being around it. And he just started 
charging after me and I started running to my car as fast as I could. And he got into the car and he threw me down in the seat and he just kept punching me, punching me.

Regardless of whether they consumed it in groups, $65 \%$ of the sample's estranged partners viewed pornography, and it was reported to be involved in sexually abusive events experienced by $30 \%$ of our interviewees. But does pornography cause separation/divorce sexual assault and other forms of woman abuse? Certainly this question cannot be answered from the data generated by this study. Rather, it requires a long-term and expensive longitudinal research design. Indeed, there are some important competing arguments. For example, it may well be that for men who are physically and sexually abusing women, pornography is just one more weapon in their arsenal. Thus, a man who knows that his partner would be scared or angry might not try to expose her to the lessons he learned from a pornographic movie, whereas his abusive friend might try to force his estranged partner to act out such scenes over her objections (Schwartz \& DeKeseredy, 1998). In a somewhat related argument, it might very well be that the same factors that cause a man to abuse women also cause him to purchase pornography. In other words, the abuse came first, followed by an interest in pornography. In these scenarios, eliminating pornography might not have an effect on the amount of woman abuse because the men are generally abusive anyway. However, this study and those that focus on other groups of women demonstrate that pornography certainly is a component of the problem of woman abuse (Bergen \& Bolgle, 2000; DeKeseredy \& Schwartz, 1998a; Harmon \& Check, 1989).

\section{Discussion}

The data gathered by this exploratory study yield several conclusions. First, separation/divorce sexual assault occurs in some rural sections of Ohio as it probably does in other parts of North America. Furthermore, like many survivors of marital rape and other forms of woman abuse, most of the women we interviewed experienced multiple forms of victimization, including physical violence. This finding is consistent with previous studies that reveal the prevalence of "battering rapes" among women who are both physically and sexually assaulted by their partners (Bergen, 1996; Bergen \& Bukovec, in press; Finkelhor \& Yllo, 1985; Russell, 1990). Consider, too, that many participants were emotionally pressured to have sex against their will. This is not surprising, given 79\% of the women stated that the men who abused them strongly believed that they "should be in charge." As Bergen and Bukovec (in press) reminded us, "Men who believe that they have a right, or entitlement to sex within their intimate partnerships, often rely on emotional pressure or coercion to force their partners to comply."

The qualitative data presented here also provide further evidence that the sexual abuse of women is fostered by male peer support. Thus, although the bulk of previous studies on this problem have been done on college campuses, this study provides additional 
evidence showing that men in a variety of locations are affected by patriarchal male peer group discourses and practices. As Bowker (1983) pointed out, any male support for the development of a sexist subculture of violence is not restricted to one specific time, place, or sociodemographic group. In a similar manner, Websdale (1998) uncovered evidence of a powerful "ol' boys network" that serves to dominate and oppress rural Kentucky women. Below, one respondent provides an account of how such an all-male sexist network and other symptoms of what Websdale referred to as "rural patriarchy" functioned to help stop her from leaving her abusive partner:

Another time, after I finally got away from him and I was having these problems. I was, I was on drugs real heavy um, and I was trying to get away from him. He was still calling me. This was just in the last nine months. Um, I called Victim Awareness in my town and um, told them that I had been abused by him. Oh, they kept telling me that they was going to do something about it, and they never did. The one other time I went to Victim Awareness, they told me that um, they were going to question the neighbors and stuff. And the neighbors said that um, you know, they said that the neighbors didn't, didn't see or hear anything. So, they said I didn't have enough ah proof, so. Basically, nothing was ever done. He's a corrections officer in the town that I lived in, and he's friends with the sheriff and whoever else.

Like data generated by some other studies of rural women's abusive experiences (e.g., Logan, Stevenson, Evans, \& Leukefeld, 2004), our findings are based solely on women's perceptions. Still, the findings strongly suggest that to strengthen a community, and to develop one that is committed to end much pain and suffering, a commitment to the "institutionalization of feminist interests" is the keystone of any successful approach to curbing woman abuse (Mazur \& McBride-Stetson, 1995, p. 10). Achieving this goal is a major challenge, but as Websdale (1998) recommended, "Any social policy initiatives must use the structure of rural patriarchy, in all its intricate manifestations, as an essential frame of reference" (p. 194).

\section{Appendix \\ Semistructured Interview Schedule}

\section{General Background Questions}

First, I would like to ask you some general background questions. Again, I can't emphasize enough that everything you tell me will be kept completely confidential and no one will ever be able to identify you with your answers.

1. I realize that I asked you this before, but I would like to make sure that I have the right information. How did you find out about this study? 
2. How old are you?

3. In which county do you live?

4. How long have you lived there?

5. Do you live in or near a city or town, or do you live far away from the nearest town or city?

6. Is transportation a problem for you? In other words, can you get to where you want to go whenever you want or need to?

7. Right now, are you employed full- or part-time? (IF SHE SAYS YES, ASK HER WHAT SHE DOES. IF SHE IS NOT WORKING THEN ASK HER HOW SHE TRIES TO MAKE ENDS MEET.)

8. About how much money did you live on in 2002 ?

9. What is the highest level of education you have completed?

10. Have you ever been married or have you ever lived with a male romantic partner? (IF SHE ANSWERS NO, THANK HER FOR HER TIME AND POLITELY TELL HER THAT SHE IS INELIGIBLE TO PARTICIPATE IN THIS STUDY. PAY HER FOR HER TIME AND REIMBURSE HER FOR HER TRAVEL EXPENSES. THEN ASK HER IF SHE HAS ANY QUESTIONS AND GIVE HER A LIST OF SUPPORT SERVICES.)

11. Are you currently married or living with a male romantic partner? (IF SHE SAYS NO, ASK HER IF SHE IS LEGALLY OR UNOFFICIALLY SEPARATED, DIVORCED OR WIDOWED. IF SHE SAYS YES, ASK HER ABOUT HER PARTNER'S JOB STATUS, YEARLY INCOME AND EDUCATION LEVEL.)

12. Do you have any children?

13. Have you raised or helped raise someone else's child or children?

14. Do you consider yourself as belonging to any particular ethnic or racial group? (IF SHE SAYS YES, ASK HER WHICH GROUP SHE BELONGS TO.)

15. What country were you born in? (IF SHE WAS NOT BORN IN THE U.S., ASK HER WHERE SHE WAS BORN AND IF SHE IS AN IMMIGRANT OR A REFUGEE FROM ANOTHER COUNTRY.)

16. Do you have a religious affiliation?

\section{Perceptions of Safety}

The next questions are about how safe you generally feel at home and in your community.

17. How much of a problem do you think there is with crime in your community?

18. How safe do you generally feel being alone in public places in your community?

19. How safe do you generally feel when you are at home?

20. Do you feel safer alone at home or when someone else is with you?

21. What about women experiencing unwanted sex . . . do you think this is a big problem in your community, some problem, or almost no problem? (PROBE: CAN YOU ELABORATE ON THAT?)

22. Do you think rape or sexual assault is a big problem in your community, some problem, or almost no problem? (PROBE: CAN YOU ELABORATE ON THAT?) 


\section{Social Network}

The next questions are about your relations with neighbors, friends and other members of your community.

23. How often do you get together with friends in your community in a typical week?

24. How often do you get together with your neighbors in a typical week?

25. Could you count on your neighbors to help you solve your personal problems?

26. Could you count on friends in your community to help you solve your personal problems?

27. Have you personally known any women who've been raped or sexually assaulted? (IF SHE SAYS YES, ASK HER TO TELL YOU HOW MANY.)

\section{Unwanted Sexual Experiences}

Many women in Ohio and other parts of the U.S. experience a wide range of unwanted sexual experiences when they want to end or have ended a relationship with their husbands or live-in male partners. Their experiences could have occurred anywhere and at any time and don't always involve force. Also, unwanted sexual experiences could occur while women are awake, asleep, unconscious, drunk, or otherwise incapacitated.

I realize that it may be difficult to discuss your own unwanted sexual experiences, but if I may, I would like to ask you some sensitive questions.

Feel free to stop me at any time, and if you feel uncomfortable with a question, please let me know.

28. At any time in your life, did your husband or live-in male partner ever try to make you have unwanted sex when you wanted to leave him or after you left him? (IF SHE SAYS YES, ASK HER WHAT HAPPENED AND ASK HER IF IT HAPPENED OFTEN. ALSO, BE PREPARED FOR RESPONDENTS TO ASK YOU TO CLARIFY WHAT YOU MEAN BY UNWANTED SEX AND BY THE TERM “TRY.” IF SHE SAYS NO, SKIP TO QUESTION 32.)

29. When did it happen?

30. Why do you think he (or they) did this?

31. In addition to trying to make you have unwanted sex, did this man (or these men) ever hurt you in other ways? (PROBE: DESTROYING YOUR PRIZED POSSESSIONS, HIT YOU, EMOTIONALLY HURT YOU, OR HURT YOUR PETS OR CHILDREN?)

32. At any time in your life, did your husband or live-in male partner ever make you have unwanted sex when you wanted to leave him or after you left him? (IF SHE SAYS YES, ASK HER WHAT HAPPENED AND ASK HER IF IT HAPPENED OFTEN. ALSO, BE PREPARED FOR RESPONDENTS TO ASK YOU TO CLARIFY WHAT YOU MEAN BY THE TERM “MAKE.” IF SHE SAYS NO, SKIP TO QUESTION 36.)

33. When did it happen?

34. Why do you think he (or they) did this? 
35. In addition to making you have unwanted sex, did this man (or men) ever hurt you in other ways? (PROBE: DESTROYING YOUR PRIZED POSSESSIONS, HIT YOU, EMOTIONALLY HURT YOU, OR HURT YOUR PETS OR CHILDREN?)

36. Did the man (or men) who tried and/or made you have unwanted sex when you wanted to leave or after you left him ever look at pornography?

37. Did the man (or men) who tried and/or made you have unwanted sex when you wanted to leave or after you left him ever make you look at pornography?

38. Did he (or did they) spend a lot of time with his male friends? (IF SHE SAYS YES, ASK HER TO TELL YOU WHAT HE USUALLY DID OR DOES WITH HIS FRIENDS.)

39. Does he (or did they) have friends who hit women or who sexually assault them?

40. Does he (or do they) feel that men should be in charge at home?

41. Did he (or they) use drugs or alcohol before he (or they) tried and/or made you have unwanted sex with him (or them)?

42. Did he (or they) try to or make you use drugs or alcohol before he (or they) tried or made you have unwanted sex with him (or them)?

43. Are there other things you would like to tell me about the man (or men) who tried or made you have unwanted sex that you think are important?

\section{Consequences of Unwanted Separation/ Divorce Sexual Assault}

Now, I would like to ask you a question about the effects of your unwanted sexual experiences.

44. How much effect did your unwanted sexual experiences have on your life? (PROBE: EMOTIONAL, PHYSICAL, ECONOMIC, SEXUAL EFFECTS?)

\section{Experiences With Social Support Providers}

Some people turn to others for help stopping or dealing with unwanted sexual experiences that occurred when they wanted to end or have ended a relationship with their husbands or live-in male partners. We would like to know about the help you asked for and/or received.

45. Do you feel different from other women who have experienced unwanted sex or other types of abuse?

46. Did you turn to anyone for help? (IF SHE SAYS YES, ASK HER WHO SHE TURNED TO AND ASK HER HOW SATISFIED SHE WAS WITH THE HELP SHE RECEIVED. IF SHE SAYS NO, ASK HER WHY SHE DIDN'T TURN TO ANYONE FOR HELP AND THEN GO TO THE QUESTIONS ABOUT SURVIVORS POLICY RECOMMENDATIONS IN THE NEXT SECTION.)

47. Who gave you the best help and did their support make you safer?

48. Who gave you the worst help? (ASK HER TO ELABORATE.) 


\section{Survivors' Policy Recommendations}

As you know, we want to make women's lives safer. So, now we would like to know what YOU think are the best ways of preventing women from experiencing unwanted sex when they want to leave or have left their husbands or live-in male partners. We would also like to know what you think could be done to improve the criminal justice system's response to problems like yours.

49. What do you think is the most effective way of preventing unwanted sex during and after separation/divorce?

50. How can the criminal justice system be more helpful to survivors of unwanted sex during and after separation/divorce?

51. How can other types of social support, such as shelters, counselors, your friends, etc., be more helpful to survivors of unwanted sex during and after separation/divorce?

52. What would you do if you were in charge of developing policies aimed at preventing unwanted sex during and after separation/divorce in your community?

53. What advice would you give to other women who have had unwanted sexual experiences when they wanted to leave or have left their husbands or male live-in partners?

\section{Plans for the Future}

54. What are your plans for the future?

55. What is your biggest concern right now? (PROBE: ARE YOU MOST CONCERNED ABOUT YOUR SAFETY, LEGAL ISSUES, FINDING A PLACE TO LIVE, MONEY, ETC.?)

\section{Conclusion}

56. Is there anything else you would like to tell me that's important that I have not asked about?

57. Are there any questions you would like to ask me?

Thank you for your time and effort. I greatly appreciate your help and I hope that the information you gave me will help make women's lives safer. Please feel free to call me if you have any questions or have some concerns.

\section{Notes}

1. See DeKeseredy, Rogness, and Schwartz (2004) and Hardesty (2002) for in-depth reviews of the literature on male-to-female physical assaults during and after separation.

2. Raquel Kennedy Bergen, Mary Koss, Karen Bachar, and Claire Renzetti devoted a substantial amount of time and effort to helping us develop this study. 
3. Furthermore, the principal investigator (PI) and members of the research team shared their findings with all of the practitioners who helped them, and the PI served on the board of directors of an Athens, Ohio, shelter. The PI also became an active member of the Athens County Coalition Against Sexual Assault during the data-gathering phase of this project, and he is still a member of the Ohio Domestic Violence Network Board of Directors.

4. See Schwartz and DeKeseredy (1997) and Schwartz, DeKeseredy, Tait, and Alvi (2001) for more detailed information on the relationship between all-male sexist conversations, alcohol consumption, and sexual assault on the college campus.

\section{References}

Anderson, E. (1999). Code of the street: Decency, violence, and the moral life of the inner city. New York: Norton.

Arendell, T. (1995). Fathers and divorce. Thousand Oaks, CA: Sage.

Bachar, K., \& Koss, M. P. (2001). From prevalence to prevention: Closing the gap between what we know about rape and what we do. In C. M. Renzetti, J. L. Edleson, \& R. K. Bergen (Eds.), Sourcebook on violence against women (pp. 117-142). Thousand Oaks, CA: Sage.

Bergen, R. K. (1996). Wife rape: Understanding the response of survivors and service providers. Thousand Oaks, CA: Sage.

Bergen, R. K., \& Bogle, K. A. (2000). Exploring the connection between pornography and sexual violence. Violence and Victims, 15, 227-234.

Bergen, R. K., \& Bukovec, P. (in press). Men and intimate partner rape: Characteristics of men who sexually abuse their partners. Journal of Interpersonal Violence.

Bourgois, P. (1995). In search of respect: Selling crack in El Barrio. New York: Cambridge University Press.

Bowker, L. H. (1983). Beating wife-beating. Lexington, MA: Lexington Books.

Brownridge, D. A., \& Halli, S. S. (2001). Explaining violence against women in Canada. Lanham, MD: Lexington Books.

Campbell, H. (2000). The glass phallus: Pub(lic) masculinity and drinking in rural New Zealand. Rural Sociology, 65, 562-581.

Campbell, J. C. (1989). Women's response to sexual abuse in intimate relationships. Health Care for Women International, 10, 335-346.

Campbell, J. C., Webster, D., Koziol-McLain, J., Block, C., Campbell, D., \& Curry, M. (2003). Risk factors for femicide in abusive relationships. American Journal of Public Health, 93, 1089-1097.

DeKeseredy, W. S. (1990). Male peer support and woman abuse: The current state of knowledge. Sociological Focus, 23, 129-139.

DeKeseredy, W. S. (2000). Current controversies on defining nonlethal violence against women in intimate heterosexual relationships: Empirical implications. Violence Against Women, 6, 728-746.

DeKeseredy, W. S., \& Joseph, C. (2006). Separation/divorce sexual assault in rural Ohio: Preliminary results of an exploratory study. Violence Against Women, 12, 301-311.

DeKeseredy, W. S., Rogness, M., \& Schwartz, M. D. (2004). Separation/divorce sexual assault: The current state of social scientific knowledge. Aggression and Violent Behavior, 9, 675-691.

DeKeseredy, W. S., \& Schwartz, M. D. (1998a). Woman abuse on campus: Results from the Canadian national survey. Thousand Oaks, CA: Sage.

DeKeseredy, W. S., \& Schwartz, M. D. (1998b). Male peer support and woman abuse in postsecondary school courtship: Suggestions for new directions in sociological research. In R. K. Bergen (Ed.), Issues in intimate violence (pp. 83-96). Thousand Oaks, CA: Sage.

DeKeseredy, W. S., \& Schwartz, M. D. (2002). Theorizing public housing woman abuse as a function of economic exclusion and male peer support. Women's Health \& Urban Life, 1, $26-45$. 
DeKeseredy, W. S., \& Schwartz, M. D. (2005). Masculinities and interpersonal violence. In M. Kimmel, R. W. Connell, \& J. Hearn (Eds.), The handbook of studies on men and masculinities (pp. 353-366). Thousand Oaks, CA: Sage.

Ellis, D., \& DeKeseredy, W. S. (1997). Rethinking estrangement, interventions and intimate femicide. Violence Against Women, 3, 590-609.

Finkelhor, D., \& Yllo, K. (1985). License to rape: Sexual abuse of wives. New York: Holt, Rinehart \& Winston.

Fleury, R. E., Sullivan, C. M., \& Bybee, D. I. (2000). When ending the relationship does not end the violence: Women's experiences of violence by former partners. Violence Against Women, 6, 1363-1383.

Hardesty, J. L. (2002). Separation assault in the context of postdivorce parenting: An integrative review of the literature. Violence Against Women, 8, 597-621.

Harmon, P. A., \& Check, J. V. P. (1989). The role of pornography in woman abuse. Toronto, Canada: York University, LaMarsh Research Center on Violence and Conflict Resolution.

Jensen, R. (1995). Pornographic lives. Violence Against Women, 1, 32-54.

Kayser, K. (1993). When love dies: The power of marital disaffection. Boston: Beacon.

Kirkwood, C. (1993). Leaving abusive partners. Newbury Park, CA: Sage.

Koss, M. P., Gidycz, C. A., \& Wisniewski, N. (1987). The scope of rape: Incidence and prevalence of sexual aggression and victimization in a national sample of higher education students. Journal of Consulting and Clinical Psychology, 55, 162-170.

Krishnan, S. P., Hilbert, J. C., \& VanLeeuwen, D. (2001). Domestic violence and help-seeking behaviors among rural women. Results from a shelter-based study. Family Community Health, 24, 28-38.

Kurz, D. (1995). For richer, for poorer: Mothers confront divorce. New York: Routledge.

Lewis, S. H. (2003). Unspoken crimes: Sexual assault in rural America. Enola, PA: National Sexual Violence Resource Center.

Logan, T. K., Stevenson, E., Evans, L., \& Leukefeld, C. (2004). Rural and urban women's perceptions to barriers to health, mental health, and criminal justice services: Implications for victim services. Violence and Victims, 19, 37-62.

MacLean, B. D. (1996). A program of local crime-survey research for Canada. In B. D. MacLean (Ed.), Crime and society: Readings in critical criminology (pp. 73-105). Toronto, Canada: Copp Clark.

Mahoney, M. R. (1991). Legal issues of battered women: Redefining the issue of separation. Michigan Law Review, 90, 1-94.

Markman, H., \& Notarious, C. (1994). We can work it out: Making sense of marital conflict. Boulder, CO: Rockwell.

Mazur, A.G., \& McBride-Stetson, D. (1995). Introduction. In A. G. Mazur \& D. McBride-Stetson (Eds.), Comparative state feminism (pp. 272-291). London: Sage.

Ptacek, J. (1999). Battered women in the courtroom: The power of judicial responses. Boston: Northeastern University Press.

Russell, D. E. H. (1990). Rape in marriage. New York: Macmillan.

Sanday, P. R. (1990). Fraternity gang rape. New York: New York University Press.

Schechter, S. (1988). Building bridges between activists, professionals, and researchers. In K. Yllo \& M. Bograd (Eds.), Feminist perspectives on wife abuse (pp. 299-312). Newbury Park, CA: Sage.

Schwartz, M. D., \& DeKeseredy, W. S. (1997). Sexual assault on the college campus: The role of male peer support. Thousand Oaks, CA: Sage.

Schwartz, M. D., \& DeKeseredy, W. S. (1998). Pornography and the abuse of Canadian women in dating relationships. Humanity \& Society, 22, 137-154.

Schwartz, M. D., DeKeseredy, W. S., Tait, D., \& Alvi, S. (2001). Male peer support and a feminist routine activities theory: Understanding sexual assault on the college campus. Justice Quarterly, 18, 623-649.

Schwartz, M. D., \& Leggett, M. S. (1999). Bad dates or emotional trauma? The aftermath of campus sexual assault. Violence Against Women, 5, 251-271.

Sev'er, A. (1997). Recent or imminent separation and intimate violence against women: A conceptual overview and some Canadian examples. Violence Against Women, 3, 566-589. 
Sinclair, R. L. (2002). Male peer support and male-to-female dating abuse committed by socially displaced male youth: An exploratory study. Unpublished doctoral dissertation, Carleton University, Ottawa, Canada.

Tjaden, P., \& Thoennes, N. (2000). Extent, nature and consequences of intimate partner violence: Findings from the National Violence Against Women Survey. Washington, DC: U.S. Department of Justice.

Websdale, N. (1998). Rural woman battering and the justice system: An ethnography. Thousand Oaks, CA: Sage.

Weisheit, R. A., Falcone, D. N., \& Wells, L. E. (1996). Crime and policing in rural and small-town America. Prospect Heights, IL: Waveland Press.

Wilson, W. J. (1996). When work disappears: The world of the new urban poor. New York: Knopf.

Walter S. DeKeseredy is professor of criminology, justice, and policy studies at the University of Ontario Institute of Technology, Oshawa, Ontario, Canada. He has written 11 books and more than 50 scientific journal articles on a variety of topics, including woman abuse in intimate relationships and crime in public housing. He also jointly received (with Martin D. Schwartz) the 2004 Distinguished Scholar Award from the American Society of Criminology's (ASC's) Division on Women and Crime, and in 1995, he received the Critical Criminologist of the Year Award from the ASC's Division on Critical Criminology.

Martin D. Schwartz is professor of sociology at Ohio University, where he served two terms as chair. A former visiting fellow at the National Institute of Justice, he has written or edited (often with Walter DeKeseredy) 20 editions of 11 books, more than 60 refereed journal articles, and another 50 book chapters, government reports, and essays. Active in the battered woman shelter movement since the 1970s, he has received the lifetime achievement award of the American Society of Criminology's (ASC's) Division on Critical Criminology, and the Distinguished Scholar Award (with DeKeseredy) from the ASC's Division on Women and Crime. He has been coeditor, deputy editor, or a member of the editorial board of 12 journals and has won a variety of teaching and service awards, including the Ohio University title of presidential research scholar.

Danielle Fagen is a prevention/intervention professional at a private nonprofit organization that works with individuals and families affected by drug and alcohol issues in Athens, Ohio. She also is an adjunct instructor of criminal justice and social problems courses at Ohio University. She received her MA in sociology from Ohio University in August 2005.

Mandy Hall is currently a graduate student in sociology at the University of Hawaii-Manoa, where she will be working on her PhD and an advanced certificate in women's studies. She has a master's degree in sociology from Ohio University. Her areas of concentration are critical criminology, violence against women, juvenile delinquency, and drugs and crime. 